$\begin{array}{cc}\text { Türkiye Tarımsal Araştırmalar Dergisi } & \text { Turk J Agric Res } \\ \text { http://dergi.siirt.edu.tr } & \text { (2016) 3: 30-36 } \\ \text { Research Article } & \text { OÜTAD } \\ \text { ISSN: 2148-2306 } & \text { doi: 10.19159/tutad.50527 }\end{array}$

\title{
Geographical Variation in Nutrient Composition of Lotus tenuis (Waldst.\&Kit.) Populations from Seeds Collected from Different Locations*
}

\author{
Hasan Beytullah DÖNMEZ ${ }^{1}$, Ferat UZUN ${ }^{2 * *}$ \\ ${ }^{I}$ Çukurova University, Tufanbeyli Vocational School, Adana, TURKEY \\ ${ }^{2}$ Ondokuz Mayls University, Agricultural Faculty, Field Crops Department, Samsun, TURKEY
}

\begin{tabular}{ll}
\hline Received: 19.10 .2015 & Accepted: 26.11 .2015 \\
${ }^{* *}$ Corresponding author: fuzun@omu.edu.tr &
\end{tabular}

\begin{abstract}
To investigate the effect of seed origin on the nutritive value of narrowleaf birdsfoot trefoil (NBT, Lotus tenuis Waldst.\&Kit.), seeds of 86 NBT populations were collected from plants spontaneously occurring in natural pastures and rangelands located at different geographical gradients of the Black Sea Region, Turkey. Some nutrient contents of these populations regrown under the same conditions were determined. Minimum and maximum values with regard to the crude protein $(\mathrm{CP})$, acid detergent fiber (ADF), neutral detergent fiber (NDF), $\mathrm{Ca}, \mathrm{P}, \mathrm{Mg}, \mathrm{K}$ and condensed tannin contents, relative feed value, $\mathrm{Ca} \mathrm{P}^{-1}$ and $\mathrm{K}(\mathrm{Ca}+\mathrm{Mg})^{-1}$ ratios were found as 176.83 and 238.87, 201.00 and 351.61, 307.19 and $435.48,15.01$ and $21.60,2.18$ and $3.77,3.03$ and $4.02,8.43$ and $16.69,20.00$ and $31.50 \mathrm{~g} \mathrm{~kg}^{-1}$ dry matter, 189.70 and $263.41,4.73$ and $9.57,0.35$ and 0.88 , respectively. The effects of seed genotype from different altitudes $\left(\mathrm{Ca}^{-1}\right)$, latitudes (digestible dry matter and $\mathrm{ADF}$ ) and longitudes (CP and $\mathrm{Mg}$ ) on some nutrient contents and feed values were found significant $(\mathrm{P}<0.05)$. The correlations between altitude and $\mathrm{NDF}, \mathrm{P}$ and $\mathrm{Mg}$ or between latitude and $\mathrm{P}$ and $\mathrm{Mg}$ contents of populations were significant. There were no specific trends in chemical composition and the nutritive value of tested NBT populations due to geographical variation. Thus, the results suggested that all studied geographical populations can be selected to obtain the nutritionally superior forage.
\end{abstract}

Keywords: Forage, narrowleaf birdsfoot trefoil, seed origin, chemical composition, feed value

\section{Introduction}

The livestock raised at high altitudes depend mostly on the feed resources in natural pasture and rangeland habitats. Therefore, livestock productivity are depend on quality of these areas include grass species as well as legume species (Ocak et al., 2006; Sun et al., 2014). In order to improve the quality of the herbage consumed by grazing animals, it is necessary to obtain information about its chemical composition and feed value, which thereafter could be related to its capacity to satisfy the requirements of the grazing animals (Dewhurst et al., 2009).

Legumes growing in pastures increase both the productivity and nutritional value of forages (Sleugh et al., 2000). There are three perennial legumes of the Lotus genus (Fabaceae) that are important as forage in some part of the world: birdsfoot trefoil (L. corniculatus L.), narrowleaf birdsfoot trefoil (NBT, L. tenuis Waldst.\&Kit.), and greater lotus (L. uliginosus Schkuhr) (Acuña and Cuevas, 1999; Papadopoulos and Kelman, 1999). Different species of Lotus are currently used to improve pastures and hay quality where other forage legume species are not suitable (Papadopulous and Kelman, 1999). The NBT is a herbaceous perennial forage species of Mediterranean origin, is a diploid species with a taproot that grows in soils with a wide range of $\mathrm{pH}$ and water and nutrient availability, and also that is adapted to low fertility, waterlogged, and saline soils (Dear et al., 2003). It has been reported that this plant tolerates flooding, drought, and salinity (Striker et al., 2005; Acuña et al., 2010; Teakle et al., 2010). These characteristics give it added value when comparing it with other legumes such as 
alfalfa, white clover or birdsfoot trefoil. In fact, varieties of NBT are more tolerant to waterlogging or flooding, alkaline and salt conditions than any commercial varieties of birdsfoot trefoil (Clua et al., 2009). The forage plant breeding should be focussed on improving the economic sustainability of pastoral agriculture through feeding animals i.e. yields, quality and for truly sustainable livestock farming.

It seemed worthwhile to investigate the suitable fodder plants which provide high yield and reproductive performance, reduce the health problem, and develop grazing tolerant cultivars.

Although there are studies investigated the effects of seed origin or collection site, i.e., latitude and longitude as well as altitude (Dragomir et al., 2011; Mountousis et al., 2011; Singh and Todaria, 2012; Uzun and Dönmez, 2015; Uzun et al., 2015) on the nutritional status of some perennial forages, the effects of these factors on the NBT populations were not investigated. Accordingly, the nutrient composition, including condensed tannins and the nutritive value of NBT populations grown from seeds collected from pastures and rangelands located at different altitudes, latitudes and longitudes requires further study. Therefore, the present study was designed to compare genetic potentials in a single environment in terms of the nutrient composition and the nutritive value of NBT populations regrown from seed collected from different altitudes, latitudes and longitudes of the Black Sea Region, Turkey.

\section{Materials and Methods}

This study was conducted at Ondokuz Mayis University, Samsun, Turkey for assessing effect of seed origin on the nutrient compositions and the nutritive value of NBT populations. L. tenuis seeds were obtained from naturalized populations of the Black Sea Region, Turkey. Therefore, the seeds of
NBT populations were collected from different altitudes ( 1 to $1510 \mathrm{~m}$ a.s.l.), latitudes $\left(40^{\circ} 06^{\prime}\right.$ to $\left.42^{\circ} 03^{\prime} \mathrm{N}\right)$ and longitudes $\left(31^{\circ} 33^{\prime}\right.$ to $\left.37^{\circ} 32^{\prime} \mathrm{E}\right)$ ranges (Table 1) from July to September. The seeds were collected from mature pods of approximately 50 mature plants spontaneously occurring in natural pasture and rangelands, grazed by livestock throughout year, of studied region (Uzun et al., 2015). The seeds from each altitude, latitude and longitude were sown in nursery beds and then grown under the same climatic conditions in the experimental area at the Black Sea Agricultural Research Institute (situated at $41^{\circ} 17^{\prime} \mathrm{N}$ latitude, $36^{\circ} 21^{\prime} \mathrm{E}$ longitude and $4 \mathrm{~m}$ a.s.l. altitude). The local climate is mild and humid, with a mean annual temperature of $14.4{ }^{\circ} \mathrm{C}$ ranging from $3.1{ }^{\circ} \mathrm{C}$ in winter to $16.7^{\circ} \mathrm{C}$ in summer and with a mean annual rainfall of $675.1 \mathrm{~mm}$ during the study period (Anonymous, 2015).

Initially, from each of 86 NBT populations representing all the seedlings, approximately $2 \mathrm{~kg}$ of tissue sample was freshly harvested and bulk sample was mixed thoroughly. Then, only $0.5 \mathrm{~kg}$ was finally dried at $60{ }^{\circ} \mathrm{C}$ for $72 \mathrm{~h}$ to determine the dry matter (DM) content and were grinded using mill having a sieve of $1 \mathrm{~mm}$. The crude protein (CP), acid detergent fibre (ADF), neutral detergent fibre $(\mathrm{NDF})$, calcium $(\mathrm{Ca})$, magnesium $(\mathrm{Mg})$ and potassium $(\mathrm{K})$ contents of these samples from NBT populations were determined by using nearinfrared reflectance spectroscopy (NIRS). The near-infrared spectra were collected with a monochromator (FOSS NIR Systems 6500, Silver Spring, MD, USA), by scanning the 400-2500 nm spectral range. All spectra and reference data were recorded and managed with the WINISI version 1.6 software (Infrasoft International, Port Matilda, PA, USA). The calibration set was analyzed for CP concentration (Anonymous, 2000a). The condensed tannin (CT) contents were determined as described by Ramírez-Restrepo et al. (2006).

Table 1. Altitudes and positions of collection sites of Lotus tenuis

\begin{tabular}{lccc}
\hline Provenance & Altitude (m a.s.1.) & Latitude (N) & Longitude (E) \\
\hline Amasya & $198-995$ & $40^{\circ} 17^{\prime} 16.0^{\prime \prime}-40^{\circ} 52^{\prime} 53.1^{\prime \prime}$ & $35^{\circ} 05^{\prime} 52.8^{\prime \prime}-36^{\circ} 28^{\prime} 54.0^{\prime \prime}$ \\
Bartın & $13-312$ & $41^{\circ} 06^{\prime} 36.5^{\prime \prime}-41^{\circ} 43^{\prime} 32.9^{\prime \prime}$ & $32^{\circ} 19^{\prime} 31.2^{\prime \prime}-32^{\circ} 38^{\prime} 27.1^{\prime \prime}$ \\
Bolu & $628-769$ & $40^{\circ} 43^{\prime} 55.9^{\prime \prime}-41^{\circ} 02^{\prime} 47.5^{\prime \prime}$ & $31^{\circ} 33^{\prime} 56.9^{\prime \prime}-32^{\circ} 04^{\prime} 49.9^{\prime \prime}$ \\
Çankırı & $870-870$ & $40^{\circ} 54^{\prime} 41.3^{\prime \prime}-40^{\circ} 54^{\prime} 41.3^{\prime \prime}$ & $33^{\circ} 37^{\prime} 18.1^{\prime \prime}-33^{\circ} 37^{\prime} 18.1^{\prime \prime}$ \\
Çorum & $415-501$ & $40^{\circ} 58^{\prime} 42.5^{\prime \prime}-40^{\circ} 59^{\prime} 32.1^{\prime \prime}$ & $34^{\circ} 38^{\prime} 36.8^{\prime \prime}-34^{\circ} 55^{\prime} 44.6^{\prime \prime}$ \\
Karabük & $305-940$ & $40^{\circ} 56^{\prime} 08.4^{\prime \prime}-41^{\circ} 23^{\prime} 12.9^{\prime \prime}$ & $32^{\circ} 28^{\prime} 36.0^{\prime \prime}-32^{\circ} 43^{\prime} 27.2^{\prime \prime}$ \\
Kastamonu & $19-1510$ & $40^{\circ} 58^{\prime} 07.1^{\prime \prime}-41^{\circ} 53^{\prime} 36.0^{\prime \prime}$ & $33^{\circ} 00^{\prime} 08.0^{\prime \prime}-35^{\circ} 52^{\prime} 53.4^{\prime \prime}$ \\
Ordu & $4-27$ & $41^{\circ} 01^{\prime} 18.2^{\prime \prime}-41^{\circ} 09^{\prime} 35.0^{\prime \prime}$ & $37^{\circ} 12^{\prime} 19.0^{\prime \prime}-37^{\circ} 32^{\prime} 34.2^{\prime \prime}$ \\
Samsun & $245-950$ & $40^{\circ} 52^{\prime} 55.3^{\prime \prime}-41^{\circ} 07^{\prime} 13.5^{\prime \prime}$ & $35^{\circ} 22^{\prime} 45.0^{\prime \prime}-35^{\circ} 26^{\prime} 43.7^{\prime \prime}$ \\
Sinop & $5-18$ & $41^{\circ} 58^{\prime} 05.0^{\prime \prime}-42^{\circ} 03^{\prime} 06.0^{\prime \prime}$ & $34^{\circ} 25^{\prime} 20.3^{\prime \prime}-35^{\circ} 02^{\prime} 03.0^{\prime \prime}$ \\
Tokat & $220-1165$ & $40^{\circ} 06^{\prime} 36.0^{\prime \prime}-40^{\circ} 40^{\prime} 50.0^{\prime \prime}$ & $36^{\circ} 18^{\prime} 16.0^{\prime \prime}-37^{\circ} 20^{\prime} 59.0^{\prime \prime}$ \\
Zonguldak & $1-103$ & $41^{\circ} 13 ' 53.5^{\prime \prime}-41^{\circ} 34^{\prime} 07.6^{\prime \prime}$ & $31^{\circ} 58^{\prime} 29.0^{\prime \prime}-32^{\circ} 09^{\prime} 43.2^{\prime \prime}$ \\
\hline
\end{tabular}


Each nutrient was analyzed with three replicated samples of altitudinal, latitudinal and longitudinal NBT populations.

As described by Moore and Undersander (2002) digestible DM (DDM) and DM intake (DMI) was calculated from percentage ADF and NDF values using the following equations, respectively; DDM $(\%)=88.9-(0.779 \times \% \mathrm{ADF})$ and DMI ( $\%$ of body weight $)=120 / \%$ NDF. Metabolizable energy (ME) was estimated using the following equation; $\mathrm{ME}(\mathrm{MJ} / \mathrm{kg} \mathrm{DM})=0.17 \%$ DDM-2.0. Relative feed value (RFV) was estimated from DDM and DMI using the following equation; $\mathrm{RFV}=(\mathrm{DDM} \times \mathrm{DMI}) / 1.29$. The tetany ratio is calculated on an equivalent weight basis using a so-called tetany ratio $[\mathrm{K} /(\mathrm{Ca}+\mathrm{Mg})]$.

All the statistical analyses were performed using SPSS software package, version 17.0 (SPSS Inc., Chicago, USA). The NBT populations were studied by multifactor analysis of variance, including the effects of altitudes, latitudes, longitudes, and their interactions. Because the interaction effects of these factors on any of the studied parameters were not significant, these were not shown in the tables and elsewhere. Pearson's correlation analysis was performed to assess the association between different experimental parameters in each of factors. When the F-test was significant, differences were compared using Tukey test at a significance level of $\mathrm{P}<0.05$. Results are presented as means and a pooled standard error of mean.

\section{Results and Discussion}

In the first part of the present study, the morphologic, agronomic and phonologic traits of
86 NBT populations and the relationships between these traits and geographical features of the natural habitats were determined (Uzun et al., 2016). The results from this study indicated that NBT populations were present in all ranges of altitude, although there was a decrease in present frequency of NBT with increasing altitude. Indeed, the ratio of gathered NBT populations were $41 \%$ in $0-300$ $\mathrm{m}, 25 \%$ in $301-600 \mathrm{~m}, 20 \%$ in $601-900 \mathrm{~m}, 12 \%$ in 901-1200 $\mathrm{m}$ and $2 \%$ in $1201-1510 \mathrm{~m}$ altitude. Similar suggestions reported by Vignolio et al. (2009) for the NBT populations naturalized in the Flooding Pampa grasslands.

The correlation coefficients between altitude and NDF, phosphorus (P) and $\mathrm{Mg}$ contents or between latitude and $\mathrm{P}$ and $\mathrm{Mg}$ contents of NBT populations were significant (Table 2). There were obvious the effects of seed genotypes from different altitudes $\left(\mathrm{Ca} \mathrm{P}^{-1}, \quad \mathrm{P}<0.05\right)$, latitudes (DDM and $\mathrm{ADF}, \mathrm{P}<0.05)$ and longitudes ( $\mathrm{CP}$ and $\mathrm{Mg}, \mathrm{P}<0.05)$ on DDM, ADF, CP, $\mathrm{Mg}$ and $\mathrm{Ca} \mathrm{P}^{-1}$ values (Table 3 and Table 4). These results can be related to the apparent high adaptability of the NBT that its spontaneous presence in this zone is very notorious (Acuña et al., 2012). Variations in quality of NBT populations also indicates their inherent ability to obtain nutrients from the soil and convert them to plant tissue with a favourable leaf to stem ratio in terms of $\mathrm{CP}, \mathrm{ADF}, \mathrm{NDF}, \mathrm{ME}$ and RFV as well as mineral contents and ratios between minerals (Vignolio et al., 2009; Dragomir et al., 2011). Therefore, seeds selected from the NBT populations that have high nutrient composition can use to increase the plant population of pasture or rangelands. The nutritive value and mineral contents of the NBT populations were within the normal range and also were found

Table 2. Descriptive statistic and correlation coefficients between geography and the nutritive value, mineral and condense tannin contents of Lotus tenuis from different geographical sites

\begin{tabular}{lrrrrrrr}
\hline & \multicolumn{3}{c}{ Descriptive statistic } & \multicolumn{3}{c}{ Correlation coefficient } \\
\cline { 2 - 7 } & Mean & SD & Minimum & Maximum & Altitude & Latitude & Longitude \\
\hline DDM, \% & 69.50 & 1.96 & 61.51 & 73.24 & -0.201 & -0.201 & -0.189 \\
DMI, \% of body weight & 3.48 & 0.27 & 2.82 & 3.96 & -0.205 & -0.162 & 0.158 \\
RFV & 232.09 & 17.38 & 189.70 & 263.41 & -0.206 & -0.164 & -0.159 \\
ME, MJ kg dry matter (DM) & 9.82 & 0.33 & 8.46 & 10.45 & -0.200 & -0.200 & -0.189 \\
$\mathrm{CP}, \mathrm{g} \mathrm{kg}^{-1} \mathrm{DM}$ & 212.01 & 12.50 & 176.83 & 238.87 & -0.194 & -0.187 & -0.209 \\
$\mathrm{ADF}, \mathrm{g} \mathrm{kg}^{-1} \mathrm{DM}$ & 248.97 & 25.11 & 201.00 & 351.61 & 0.201 & 0.201 & 0.189 \\
$\mathrm{NDF}, \mathrm{g} \mathrm{kg}^{-1} \mathrm{DM}$ & 351.67 & 28.33 & 307.19 & 435.48 & $0.227^{*}$ & 0.190 & 0.183 \\
$\mathrm{Ca}, \mathrm{g} \mathrm{kg}^{-1} \mathrm{DM}$ & 18.56 & 1.24 & 15.01 & 21.60 & -0.010 & -0.029 & -0.590 \\
$\mathrm{P}, \mathrm{g} \mathrm{kg}^{-1} \mathrm{DM}$ & 2.98 & 0.33 & 2.18 & 3.77 & $-0.260^{*}$ & $-0.228^{*}$ & -0.196 \\
$\mathrm{Ca} \mathrm{P}$ & 6.49 & 1.09 & 4.73 & 9.57 & 0.189 & 0.156 & 0.123 \\
$\mathrm{Mg}, \mathrm{g} \mathrm{kg}^{-1} \mathrm{DM}$ & 3.50 & 0.20 & 3.03 & 4.02 & $0.225^{*}$ & $0.232^{*}$ & 0.188 \\
$\mathrm{~K}, \mathrm{~g} \mathrm{~kg}^{-1} \mathrm{DM}$ & 11.89 & 1.81 & 8.43 & 16.69 & -0.117 & 0.074 & -0.500 \\
$\mathrm{~K}\left(\mathrm{Ca}_{\mathrm{Mgg}} \mathrm{MM}^{-1}\right.$ & 0.56 & 0.12 & 0.35 & 0.88 & -0.048 & -0.004 & 0.220 \\
$\mathrm{CT}, \mathrm{g} \mathrm{kg}^{-1} \mathrm{DM}$ & 24.10 & 2.73 & 20.00 & 31.51 & -0.138 & -0.107 & -0.106 \\
\hline
\end{tabular}

Values are means of 86 populations with three replicates. DDM: Digestible dry matter, DMI: Dry matter intake, RFV: Relative feed value, ME: Metabolizable energy, CP: Crude protein, ADF: Acid detergent fiber, NDF: Neutral detergent fiber, Ca: Calcium, P: Phosphorus, Mg: Magnesium, K: Potassium, CT: Condensed tannin, ${ }^{*}$ : Significant at $\mathrm{P}<0.05$ 
to be comparable with other legumes (Dynes et al., 2003; Acuña et al., 2012). Moreover, they were within values recommended by the Anonymous (2000b, 2001, 2007) and confirmed other scientific suggestions (Moniello et al., 2005). All have excellent feed quality for ruminants; $12-25 \%$ crude protein content and dry matter digestibility of 50$73 \%$ (Cook et al., 2005). Thus, our findings indicated that the maintenance requirements of grazing livestock may meet until late autumn without additional protein and energy sources.
Protein, necessary for muscle development, growth and milk production is an important nutrient in animal production and is generally least expensive if supplied by forages. The CP contents of the NBT populations were in the same range as reported by Dynes et al. (2003) and Acuña et al. (2012). As reported by Dragomir et al. (2011), the nutritional value, calculated through the determination of some quality indices (CP, ADF and NDF), proved that there are not important differences between the studied geographical sites.

Table 3. Altitudinal, latitudinal and longitudinal variations in nutritive value of Lotus tenuis from different geographical sites

\begin{tabular}{ccccccccc}
\hline & $\mathrm{n}$ & DDM & DMI & RFV & ME & CP & ADF & NDF \\
\hline Altitude & & & & & & & & \\
\hline$<400$ & 39 & 69.82 & 3.50 & 233.73 & 9.87 & 215.11 & 244.97 & 348.35 \\
$401-800$ & 29 & 69.46 & 3.50 & 233.74 & 9.81 & 209.69 & 249.54 & 349.71 \\
$>801$ & 18 & 68.90 & 3.38 & 225.87 & 9.71 & 209.06 & 256.75 & 361.99 \\
\hline & P-value & 0.257 & 0.233 & 0.235 & 0.257 & 0.110 & 0.257 & 0.218 \\
\hline Latitude & & & & & & & & \\
\hline $40^{\circ} 06^{\prime}-40^{\circ} 58^{\prime}$ & 44 & $69.86 \mathrm{a}$ & 3.51 & 234.17 & 9.88 & 213.88 & $244.40 \mathrm{~b}$ & 347.45 \\
$41^{\circ} 59^{\prime}-42^{\circ} 03^{\prime}$ & 42 & $69.13 \mathrm{~b}$ & 3.44 & 229.91 & 9.75 & 210.06 & $253.77 \mathrm{a}$ & 356.08 \\
\hline & P-value & 0.043 & 0.263 & 0.259 & 0.054 & 0.157 & 0.048 & 0.159 \\
\hline Longitude & & & & & & & & \\
\hline $31^{\circ} 33^{\prime}-32^{\circ} 43^{\prime}$ & 27 & 70.00 & 3.50 & 233.58 & 9.90 & $218.00 \mathrm{a}$ & 242.66 & 348.04 \\
$33^{\circ} 00^{\prime}-33^{\circ} 59^{\prime}$ & 9 & 69.14 & 3.47 & 231.87 & 9.75 & $214.81 \mathrm{ab}$ & 253.64 & 352.40 \\
$34^{\circ} 01^{\prime}-34^{\circ} 55^{\prime}$ & 8 & 70.22 & 3.58 & 238.75 & 9.94 & $210.18 \mathrm{ab}$ & 239.87 & 339.90 \\
$35^{\circ} 02^{\prime}-35^{\circ} 65^{\prime}$ & 17 & 69.01 & 3.53 & 235.91 & 9.73 & $205.97 \mathrm{~b}$ & 255.28 & 346.93 \\
$36^{\circ} 11^{\prime}-36^{\circ} 55^{\prime}$ & 19 & 69.36 & 3.39 & 226.76 & 9.79 & $213.64 \mathrm{ab}$ & 250.88 & 361.06 \\
$37^{\circ} 12^{\prime}-37^{\circ} 32^{\prime}$ & 6 & 68.75 & 3.33 & 222.91 & 9.69 & $210.31 \mathrm{ab}$ & 258.66 & 366.25 \\
\hline & P-value & 0.405 & 0.349 & 0.345 & 0.414 & 0.013 & 0.405 & 0.312 \\
\hline
\end{tabular}

SEM: Standard error of the mean, DDM: Digestible dry matter (\%), DMI: Dry matter intake (\% of body weight), RFV: Relative feed value (g kg DM), ME: Metabolizable energy ( $\left.\mathrm{MJ} \mathrm{kg}^{-1} \mathrm{DM}\right), \mathrm{CP}$ : Crude protein $\left(\mathrm{g} \mathrm{kg}^{-1} \mathrm{DM}\right)$, ADF: Acid detergent fiber $\left(\mathrm{g} \mathrm{kg}^{-1} \mathrm{DM}\right)$, NDF: Neutral detergent fiber $\left(\mathrm{g} \mathrm{kg}^{-1} \mathrm{DM}\right)$, a, b: Different superscripts within the same column indicate significant differences $(\mathrm{P}<0.05)$

Table 4. Altitudinal, latitudinal and longitudinal variations in mineral and condense tannin contents of Lotus tenuis from different geographical sites

\begin{tabular}{|c|c|c|c|c|c|c|c|c|}
\hline & $\mathrm{n}$ & $\mathrm{Ca}$ & $\mathrm{P}$ & $\mathrm{Ca} / \mathrm{P}$ & $\mathrm{Mg}$ & $\mathrm{K}$ & $\mathrm{K} /(\mathrm{Ca}+\mathrm{Mg})$ & $\mathrm{CT}$ \\
\hline \multicolumn{9}{|l|}{ Altitude } \\
\hline$<400$ & 39 & 18.72 & 3.02 & $6.45 \mathrm{ab}$ & 3.47 & 11.84 & 0.54 & 24.34 \\
\hline $401-800$ & 29 & 18.28 & 3.02 & $6.28 \mathrm{~b}$ & 3.50 & 12.25 & 0.58 & 24.26 \\
\hline \multirow[t]{2}{*}{$>801$} & 18 & 18.66 & 2.83 & $6.94 \mathrm{a}$ & 3.57 & 11.43 & 0.54 & 23.30 \\
\hline & P-value & 0.327 & 0.052 & 0.024 & 0.177 & 0.321 & 0.298 & 0.380 \\
\hline \multicolumn{9}{|l|}{ Latitude } \\
\hline $40^{\circ} 06^{\prime}-40^{\circ} 58^{\prime}$ & 44 & 18.67 & 3.02 & 6.44 & 3.46 & 11.89 & 0.55 & 24.30 \\
\hline \multirow[t]{2}{*}{$41^{\circ} 59^{\prime}-42^{\circ} 03^{\prime}$} & 42 & 18.45 & 2.94 & 6.55 & 3.54 & 11.90 & 0.56 & 23.88 \\
\hline & P-value & 0.414 & 0.283 & 0.634 & 0.053 & 0.969 & 0.503 & 0.481 \\
\hline \multicolumn{9}{|l|}{ Longitude } \\
\hline $31^{\circ} 33^{\prime}-32^{\circ} 43^{\prime}$ & 27 & 18.60 & 3.06 & 6.31 & $3.46 \mathrm{~b}$ & 12.03 & 0.55 & 24.48 \\
\hline $33^{\circ} 00^{\prime}-33^{\circ} 59^{\prime}$ & 9 & 19.44 & 2.84 & 7.14 & $3.56 \mathrm{ab}$ & 10.97 & 0.49 & 24.20 \\
\hline $34^{\circ} 01^{\prime}-34^{\circ} 55^{\prime}$ & 8 & 18.04 & 3.08 & 6.10 & $3.38 b$ & 12.43 & 0.59 & 23.82 \\
\hline $35^{\circ} 02^{\prime}-35^{\circ} 65^{\prime}$ & 17 & 18.27 & 3.00 & 6.34 & $3.55 \mathrm{ab}$ & 12.17 & 0.58 & 23.65 \\
\hline $36^{\circ} 11^{\prime}-36^{\circ} 55^{\prime}$ & 19 & 18.47 & 2.95 & 6.57 & $3.50 \mathrm{~b}$ & 11.95 & 0.57 & 24.32 \\
\hline \multirow[t]{3}{*}{$37^{\circ} 12^{\prime}-37^{\circ} 32^{\prime}$} & 6 & 18.88 & 2.76 & 7.10 & $3.66 \mathrm{a}$ & 10.99 & 0.50 & 24.16 \\
\hline & P-value & 0.200 & 0.239 & 0.206 & 0.049 & 0.416 & 0.245 & 0.870 \\
\hline & SEM & 0.134 & 0.352 & 0.118 & 0.021 & 0.196 & 0.012 & 0.294 \\
\hline
\end{tabular}

SEM: Standard error of the mean, Ca: Calcium $\left(\mathrm{g} \mathrm{kg}^{-1} \mathrm{DM}\right)$, P: Phosphorus $\left(\mathrm{g} \mathrm{kg}^{-1} \mathrm{DM}\right), \mathrm{Mg}$ : Magnesium $\left(\mathrm{g} \mathrm{kg}^{-1} \mathrm{DM}\right), \mathrm{K}^{-}$Potassium $\left(\mathrm{g} \mathrm{kg}{ }^{-1} \mathrm{DM}\right)$, CT: Condensed tannin $\left(\mathrm{g} \mathrm{kg}^{-1} \mathrm{DM}\right)$, a, b: Different superscripts within the same column indicate significant differences $(\mathrm{P}<0.05)$ 
In the present study, the correlation between $\mathrm{CP}$ and altitude does not support that $\mathrm{N}$ concentration of leaf increased from the tropics to mid-latitudes and then remained stable or decreased at high latitudes (Reich and Oleksyn, 2004) and that nitrogen $(\mathrm{N})$ concentration in plants increased with the latitudinal (Han et al., 2012) and the altitudinal gradient (Singh and Todaria, 2012). In contrast to our results, Mountousis et al. (2011) reported that $\mathrm{NDF}, \mathrm{ADF}$ and gross energy contents of forages were affected by the altitudinal zone as well as by the season.

The DMI and ME are a positive indicator of forage quality and an important component that makes up the diet of animals (Arzani et al., 2005). Waghorn and Clark (2004) noted that the ME content of forages provides a guide to nutritive value but ignores other components that affect intake, digestion and the products of digestion that are absorbed and metabolized to provide substrates for maintenance and production. Although herbage ME content was lower in the lowlands owing to faster maturation of plants as a result of higher air temperatures (Mountousis et al., 2011), this effect was not reflected on that of NBT populations from different altitudes, latitudes and longitudes. An increase in DDM generally leads to improve in performance by increasing DMI of ruminant animals (Ashikaga et al., 2009). In the present study, there were significant effects of the studied factors on DDM and ADF (Table 3). The minerals and the correct ratios of minerals (e.g. $\mathrm{Ca} \mathrm{P}^{-1}, \mathrm{Ca}$ $\mathrm{Mg}^{-1}, \mathrm{~K} /(\mathrm{Ca}+\mathrm{Mg})$ and $\mathrm{K} \mathrm{Mg}^{-1}$ ratios $)$ in the forage as well as $\mathrm{CP}$ and $\mathrm{ME}$ contents and RFV of fodder feeds may affect animal growth and/or performance. Based on our findings and previous reports (Striker et al., 2005; Acuña et al., 2010, 2012; Teakle et al., 2010) on advantage of NBT, populations can select for multiplication of quality forage production.

Because legumes, including NBT have higher concentrations of $\mathrm{Ca}$ and $\mathrm{Mg}$ than grasses, avoiding legume decrease in rangelands may be useful to prevent the tetany risk (Aydin and Uzun, 2008; Uzun, 2010). Risk of tetany, causing yield decrease and death in cattle and sheep, increases by feeding forage with a ratio of $\mathrm{K}(\mathrm{Ca}+\mathrm{Mg})^{-1} \geq$ 2.2 or the greater risk of grass tetany occurs at $\mathrm{K}: \mathrm{Mg}$ ratio greater than 10:1. Indeed, $\mathrm{K}(\mathrm{Ca}+\mathrm{Mg})^{-}$ ${ }^{1}$ and $\mathrm{K}: \mathrm{Mg}$ ratios in all NBT populations were very lower (Table 4) than these values, resulting in tetany risk. Deficiency of $\mathrm{P}$, an essential nutrient for all animals is the most widespread of all the mineral deficiencies affecting livestock. Besides, $\mathrm{P}$ must be balanced in the animal diet with adequate $\mathrm{Ca}$ and vitamin $\mathrm{D}$ for growth, reproduction, gestation, and lactation. The $\mathrm{Ca}: \mathrm{P}$ ratio of forage is often discussed when examining forage quality and animal performance. An acceptable $\mathrm{Ca} P \mathrm{P}$ ratio is between $1: 1$ and $7: 1$, as long as there is enough $\mathrm{P}$ to meet the nutritional requirements of livestock (Anonymous, 2000b, 2001, 2007). Therefore, the $\mathrm{Ca}: \mathrm{P}$ ratios of all NBT populations in the present study were within the desirable $\mathrm{Ca}: \mathrm{P}$ ratio range. Therefore, results on mineral concentrations and ratios between minerals of NBT populations suggest that NBT is suitable not only to prevent incidence or risky of milk fever and tetany but also to increase $\mathrm{Ca}, \mathrm{P}, \mathrm{Mg}$ and $\mathrm{K}$ utilization of the ruminant animals (Kume et al., 2001).

Perennial forage legume species, such as birdsfoot trefoil and NBT, contain condensed tannins, with severe consequences on the nutritional value of forage legumes and the health of animals eating such forage. The CT contents of NBT populations suggested that the level of secondary metabolites does not change with change in the altitude, latitude and longitude of plant origin. The CT levels of NBT populations were within normal ranges (up to $35 \mathrm{~g} \mathrm{~kg}^{-1} \mathrm{DM}$ ) which have reduced rumen degradable nitrogen and increase N-use efficiency (Acuña et al., 2012), increasing the protein absorption of the small intestine (Terrill et al., 1992; Acuña et al., 2012). Thus, grazing of pasture with NBT led to increased growth rate, fattening and reproductive performances as well as milk and meat quality (Speijers et al., 2004).

\section{Conclusions}

This study provided that nutritional information on NBT from different altitudes, latitudes and longitudes, which can be used to obtain average nutritional values in pasture management work. This study indicated that tested populations can be selected for development of new cultivars or the multi-trait indices may be a more effective tool to select quality genotypes. There were no specific trends in the chemical composition and the nutritive value of tested NBT populations when grown under the same conditions. Therefore, we recommend that the seeds of different altitudinal, latitudinal and longitudinal NBT populations could be selected for multiplication of Lotus for obtaining the nutritionally superior forage.

\section{Acknowledgements}

The authors acknowledge the financial support provided the Scientific and Technological Research Council, TUBITAK (TOVAG-1080658). The authors thanks for his critical editing of the manuscript to Dr. N. Ocak and Dr. A.V. Garipoğlu. 


\section{References}

Acuña, H.P., Cuevas, G., 1999. Efecto de la altura y frecuencia de la defoliación, bajo corte y pastoreo, en el crecimiento y productividad de tres especies del género Lotus en suelos arcillosos. Agricultura Técnica, 59(4): 296-308.

Acuña, H., Inostroza, L., Sánchez, M.P., Tapia, G., 2010. Drought tolerant naturalized populations of Lotus tenuis for constrained environments. Acta Agriculturae Scandinavica, Section B-Plant and Soil Science, 60(2): 174-181.

Acuña, H., Ortega, F., Seguel, I., Barrientos, L., 2012. Introduction, collection and characterization of Lotus spp. germplasm in Chile. Journal of Environmental Science and Engineering, 1(4): 533552.

Anonymous, 2000a. Official Methods of Analysis of the AOAC International. $17^{\text {th }}$ Edition, Gaitherburg, MD: AOAC International.

Anonymous, 2000b. National Research Council (NRC), Nutrient Requirements of Beef Cattle: $7^{\text {th }}$ Revised Edition (Update 2000), the National Academies Press, Washington, DC, USA.

Anonymous, 2001. National Research Council (NRC), Nutrient Requirements of Dairy Cattle: $7^{\text {th }}$ Revised Edition, the National Academies Press, Washington, DC, USA.

Anonymous, 2007. National Research Council (NRC), Nutrient requirements of small ruminants; sheep, goats, Cervids, and New World Camelids: $6^{\text {th }}$ Edition, The National Academy Press, Washington, DC, USA.

Anonymous, 2015. Meteorology Office Records for Provinces and Cities of Turkey. Turkish State Meteorological Service. http://www.meteror.gov.tr.

Arzani, H., Nikkhah, A., Jalili, A., 2005. An introduction of the most important factors in range species for the determination of nutrient values. Iranian Journal of Natural Resources, 57(4): 777-790.

Ashikaga, K., Tamaki, H., Sato, N., Tanaka, T., Deguchi, K., Iida, K., Sato, K., 2009. Effects of year and location on the nutritive value in the first crop of Timothy (Phleum pratense L.). Grassland Science, 55(3): 149-154.

Aydın, I., Uzun, F., 2008. Potential decrease of grass tetany risk in rangelands combining $\mathrm{N}$ and $\mathrm{K}$ fertilization with $\mathrm{MgO}$ treatments. European Journal of Agronomy, 29(1): 33-3.

Clua, A., Orsini, H., Beltrano, J., 2009. Incidence of variable flooding period on Lotus tenuis biomass production and leaf senescence. Lotus Newsletter, 39(1): 13-20.

Cook, B.G., Pengelly, B.C., Brown, S.D., Donnelly, J.L., Eagles, D.A., Franco, M.A., Hanson, J., Mullen, B.F., Partridge, I.J., Peters, M., Schultze-Kraft, R., 2005. Tropical Forages: An interactive selection tool. Lablab purpureus. CSIRO, DPI\&F (Qld), CIAT, and ILRI, Brisbane, Australia. http://www. tropicalforages.info/key/Forages/Media/Html/Lablab _purpureus.htm (Access date: 14.10.2015).
Dear, B.S., Moore, G.A., Hughes, S.J., 2003. Adaptation and potential contribution of temperate perennial legumes to the southern Australian wheatbelt. Australian Journal of Experimental Agriculture, 43(1): 1-18

Dewhurst, R.J., Delaby, L., Moloney, A., Boland, T., Lewis, E., 2009. Nutritive value of forage legumes used for grazing and silage. Irish Journal of Agricultural and Food Research, 48: 167-187.

Dragomir, C., Dragomir, N., Toth, S., 2011. Studies on several Romanian agroecotypes of birdsfoot trefoil (Lotus corniculatus L.) with special reference to their productivity and forage quality. Journal of Food, Agriculture \& Environment, 9(3\&4): 11241128.

Dynes, R.A., Henry, D.A., Masters, D.G., 2003. Characterizing forages for ruminant feeding, AsianAust. Journal of Animal Science, 16(1): 116-123.

Han, F., Yao, Y., Dai, S., Wang, C., Sun, R., Xu, J., Zhang, B., 2012. Mass elevation effect and its forcing on timberline altitude. Journal of Geographical Sciences, 22(4): 609-616.

Kume, S., Toharmat, T., Nonaka, K., Oshita, T., Nakui, T., Ternouth, J.H., 2001. Relationships between crude protein and mineral concentrations in alfalfa and value of alfalfa silage as a mineral source for periparturient cows. Animal Feed Science Technology, 93(3):157-168.

Moniello, G., Infascelli, F., Pinna, W., Camboni, G., 2005. Mineral requirements of dairy sheep. Italian Journal of Animal Science, 4(Supp. 1): 63-74.

Moore, J.E., Undersander, D.J., 2002. Relative forage quality: An alternative to relative feed value and quality index. Proceedings, $13^{\text {th }}$ Annual Florida Ruminant Nutrition Symposium, January 1011, University of Florida, USA, pp. 16-32.

Mountousis, I., Dotas, V., Stanogias, G., Papanikolaou, K., Roukos, C., Liamadis, D., 2011. Altitudinal and seasonal variation in herbage composition and energy and protein content of grasslands on $\mathrm{Mt}$ Varnoudas, NW Greece. Animal Feed Science Technology, 164 (3-4): 174-183.

Ocak, N., Çam, M.A., Kuran, M., 2006. The influence of pre- and post-mating protein supplementation on reproductive performance in ewes maintained on rangeland. Small Ruminant Research, 64(1-2): 1621.

Papadopoulos, Y., Kelman, W., 1999. Traditional breeding of Lotus species. In: P. Beuselinck (Ed), Trefoil: The Science and Technology of Lotus, American Society of Agronomy, pp. 187-198.

Ramírez-Restrepo, C.A., Barry, T.N., López-Villalobos, N., 2006. Organic matter digestibility of condensed tannin-containing Lotus corniculatus and its prediction in vitro using cellulose/hemicellulose enzymes. Animal Feed Science and Technology, 125(1-2): 61-71.

Reich, P.B., Oleksyn, J., 2004. Global patterns of plant leaf $\mathrm{N}$ and $\mathrm{P}$ in relation to temperature and latitude. Proceedings of the National Academy of Sciences, 101(30): 11001-11006. 
Singh, B., Todaria, N.P., 2012. Nutrients composition changes in leaves of Quercus semecarpifolia at different seasons and altitudes. Annals of Forest Research, 55(2): 189-196.

Sleugh, B., Moore, K.J., George, J.R., Brummer, E.C., 2000. Binary legume-grass mixtures improve forage yield, quality, and seasonal distribution. Agronomy Journal, 92(1): 24-29.

Speijers, M.H.M., Fraser, M.D., Theobald, V.J., Haresign, W., 2004. The effects of grazing forage legumes on the performance of finishing lambs. Journal of Agricultural Science, 142(4): 483-493.

Striker, G.G., Insausti, P., Grimaldi, A.A., Ploschuk, E.L., Vasellati, V., 2005. Physiological and anatomical basis of differential tolerance to soil flooding of Lotus corniculatus L. and Lotus glaber L. Plant and Soil, 276(1-2): 301-311.

Sun, Z., Wang, Z., Zhong, Q., Zhou, D., 2014. Seasonal variations in voluntary intake and apparent digestibility of forages in goats grazing on introduced Leymus chinensis pasture. AsianAustralasian Journal of Animal Science, 27(6): 818824

Teakle, N.L., Amtmann, A., Real, D., Colmer, T.D., 2010. Lotus tenuis tolerates combined salinity and waterlogging: maintaining $\mathrm{O}_{2}$ transport to roots and expression of an NHX1-like gene contribute to regulation of $\mathrm{Na}+$ transport. Physiologia Plantarum, 139(4): 358-374

Terrill, T.H., Rowan, A.M., Douglas, G.B., Barry, T.N., 1992. Determination of extractable and bound condensed tannins concentration in forage plants, protein concentrates meals and cereal grains. Journal of Food and Agriculture Science, 58(3): 321-329.

Uzun, F., 2010. Changes in hay yield and quality of bulbous barley at different phonological stages. Turkish Journal of Agriculture and Forestry, 34(1): $1-9$.

Uzun, F., Dönmez, H.B., 2015. Ecotype traits in natura populations of birdsfoot trefoil (Lotus corniculatus L.) in association to geographical parameters of sampling sites. Ekoloji, DOI: 10.5053/ekoloji. 2015.21 (In press).

Uzun, F., Dönmez, H.B., Ocak, N., 2015. Genetic potentials with regard to nutrient composition and nutritive value of wild birdsfoot trefoil (Lotus corniculatus L.) populations from seeds collected from different geographical locations. Agroforestry Systems, 89(6): 963-972.

Uzun, F., Dal, A., Dönmez, H.B., Sürmen, M., Yavuz, T., Özyazıc1, M.A., Çankaya, N., 2016. Morphological, agronomical, phenological and stand persistence traits of some wild narrowleaf birdsfoot trefoil (Lotus tenuis Waldst.\&Kit.) populations. Journal of Agricultural Sciences, 22(2), (In press).

Vignolio, O.R., Fernández, O.N., Acuña, H., 2009. Impact of the ryegrass (Lolium multiflorum Lam.) promotion practice on Lotus tenuis Waldst.\&Kit. soil seed bank and plant density. Lotus Newsletter, 39(1): $1-6$

Waghorn, G.C., Clark, D.A., 2004. Feeding value of pastures for ruminants. New Zealand Veterinary Journal, 52(6): 320-331. 